\title{
Asymmetric oxidation of substituted dithianes and dithiolanes by engineered yeast and $E$. coli expressing cyclohexanone monooxygenase
}

\author{
Margaret M. Kayser,* Hongwei Zhao, Gang Chen, and Anton Feicht \\ Department of Physical Sciences, University of New Brunswick, P.O. Box 5050, Saint John, New \\ Brunswick, Canada. \\ E-mail: kayser@unbsj.ca
}

Dedicated to Dr. Joseph M. Muchowski on his $65^{\text {th }}$ birthday

(received 09 Nov 02; accepted 28 Apr 03; published on the web 06 May 03)

\begin{abstract}
2,2-Disubstituted 1,3-dithiolanes and dithianes can be oxidized to enantiomerically and diastereomerically pure or highly enriched monosulfoxides using engineered E. coli and Saccharomyces cerevisiae (baker's yeast). The fermentations in simple shake flasks can be easily carried out in conventional chemical laboratories. The substrate types suitable for these transformations are discussed. The asymmetric syntheses of two useful optically and diastereomerically pure dithiolane monosulfoxides are reported.
\end{abstract}

Keywords: Engineered whole cells, cyclohexanone monooxygenase, oxidation of sulfides to sulfoxides, optically pure 1,3-dithianes monosulfoxides, 1,3-dithiolanes monosulfoxides

\section{Introduction}

Chiral sulfoxides are important compounds for a variety of reasons. They are valuable starting materials $^{1}$ and versatile chiral auxiliaries ${ }^{2}$ in synthetic chemistry; in natural products, they occur in functionalized amino acids that exhibit a wide range of biological activities including antibiotic properties; ${ }^{3}$ they are also found as metabolites of many sulfur-containing drugs. ${ }^{4}$

Asymmetric oxidations of sulfur are catalyzed by several classes of enzymes, such as monooxygenases, chloroperoxidases, and dioxygenases. ${ }^{5}$ One of the most studied has been the enzyme cyclohexanone monooxygenase (CHMO), from Acinetobacter sp. NCIB 9871. It oxidizes, often with good stereoselectivities, a very wide range of dialkyl sulfides, ${ }^{6,7}$ benzyl alkyl sulfides, ${ }^{8}$ alkyl aryl sulfides, ${ }^{7,9}$ dithianes, ${ }^{9}$ and dithiolanes. ${ }^{9}$

Whole-cell catalyzed reactions have an advantage over isolated enzymes insofar that enzymes do not need to be isolated and purified, and there is no need for addition of expensive 
co-factors. Preparative-scale sulfoxidations are most conveniently performed in this way, and further scale-ups are feasible. There are, however, problems associated with whole cell fermentations, the most common being over-metabolism of the product, competing reactions, and formation of contaminating metabolites. The use of recombinant organisms overexpressing the desired enzyme often allows to minimize or to avoid entirely such difficulties.

We have engineered a "designer yeast", in which CHMO is overexpressed in common baker's yeast Sacharomyces cerevisiae, ${ }^{10}$ and we have demonstrated its usefulness in performing asymmetric Baeyer-Villiger oxidations ${ }^{11}$ and oxidation of simple sulfides to sulfoxides. ${ }^{12}$ More recently, we constructed a recombinant $E$. coli strain overexpressing the same enzyme and evaluated its potential as a reagent for biooxidations of simple prochiral sulfides. ${ }^{12}$ These studies have shown that recombinant strains overexpressing CHMO are useful reagents for asymmetric Baeyer-Villiger reactions and can provide chiral sulfoxides with chemical yields and optical purities comparable to those obtained by enzymatic and traditional chemical methods. In the present study we evaluate the performance of the recombinant strains in oxidations of more complex prochiral 2-substituted dithianes and dithiolanes.

\section{Results}

Since the pioneering work of Walsh and co-workers, ${ }^{13}$ a large variety of sulfides with simple hydrocarbon chains have been investigated and have been found to be acceptable substrates for CHMO. ${ }^{6-9,14-19}$ The biotransformations using engineered organisms overexpressing the desired enzymes are often simpler, and more likely to be used by organic chemists than the reactions with isolated enzymes or with parent organisms, particularly if the parent organism requires microbiological skills or specialized equipment for handling (Acinetobacter sp., for example, is a class II pathogen). In view of that, we carried out a preliminary study of whole cell-catalyzed oxidations using our engineered yeast and E. coli. ${ }^{12}$ Several sulfides known to be good substrates for CHMO and/or Acinetobacter sp. NCIB 9871 were tested. Our results have shown that the recombinant strains can successfully carry out asymmetric oxidations at sulfur centers. There were small differences in the performance between the yeast/CHMO and E. coli/CHMOcatalyzed reactions. The latter reagent was found to be superior in some cases since it did not produce side oxidations, which occasionally occurred in the yeast/CHMO-catalyzed reactions and, in a few cases, it afforded slightly better yields. ${ }^{12}$

In the course of this study, we established that dithiane and dithiolane, as well as their 2methyl-, 2,2-dimethyl-, and 2-phenyl derivatives were readily oxidized by the recombinant organisms. With these simple compounds the conversions were essentially complete and the isolated yields of the products were high. The two other concerns which needed attention were: (1) possible overoxidation by $\mathrm{CHMO}$, and (2) competitive oxidation by oxidases native to the host strains (baker's yeast and E. coli). ${ }^{5,20,21}$ Overoxidations to sulfones were detected in a few cases. Although common to both isolated enzyme and whole cell-catalyzed reactions, 
overoxidations were slightly more important during fermentations. It should be remembered that the transport of a more polar sulfoxide out of the cell is slower than the transport of a less polar sulfide into the cell. The increased competition between sulfide and sulfoxide for the same active site results in a higher proportion of sulfone production in whole-cell mediated reactions. In order to determine possible contributions from oxidations by host organisms, control experiments were conducted for both yeast and E. coli carrier strains. These experiments have shown that oxidases native to the host strains contributed little or not at all to the reactions under investigation. $^{12}$
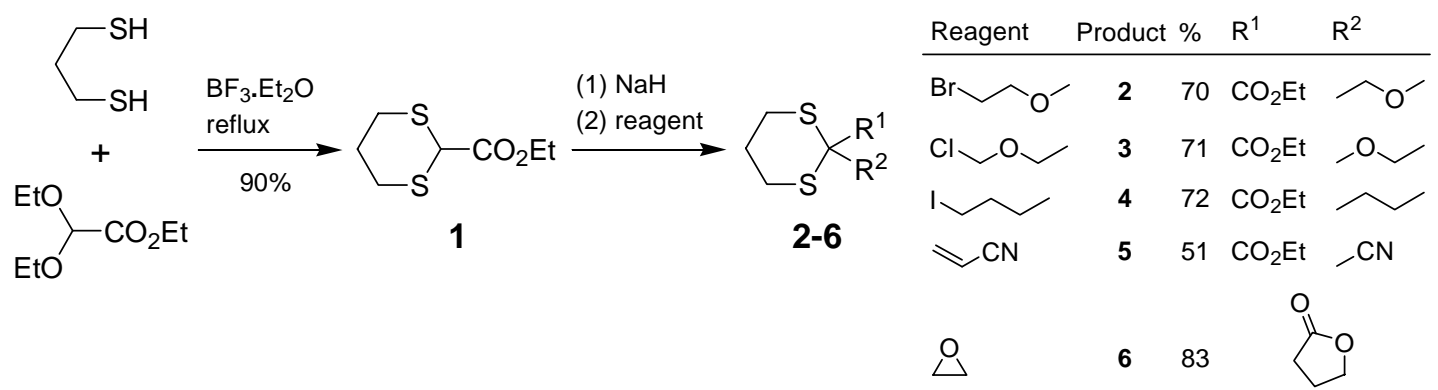

\section{Scheme 1}

\begin{tabular}{crll}
${ }_{\mathrm{S}}^{\mathrm{S}} \mathrm{K}_{\mathrm{R}^{2}}^{\mathrm{R}^{1}}$ & & $\mathrm{R}$ & $\mathrm{R}^{1}$ \\
\cline { 2 - 4 } $\mathbf{7 - 1 0}$ & $\mathbf{7}$ & $\mathrm{H}$ & $i$-Bu \\
& $\mathbf{9}$ & $\mathrm{CO}_{2}$ Et & $n$-pentyl \\
& $\mathbf{1 0}$ & $n$-Bu & $n$-Bu
\end{tabular}

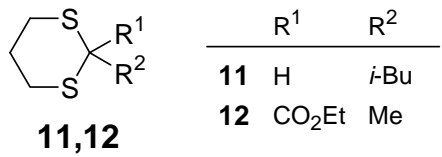

The preliminary studies outlined above encouraged us to examine further functional group compatibilities in the bio-oxidations of substituted dithianes and dithiolanes. Several of these compounds were prepared and screened as potential substrates. Ethyl 1,3-dithiane-2-carboxylate 1 was synthesized by transketalization between commercially available ethyl diethoxyacetate and 1,3-propanedithiol using $\mathrm{BF}_{3} \cdot \mathrm{Et}_{2} \mathrm{O}$ as a Lewis acid catalyst. Treatment of $\mathbf{1}$ with $\mathrm{NaH}$ gave the stabilized carbanion intermediate, which was trapped by the subsequent addition of suitable electrophiles to give substituted dithianes 2-6 (Scheme 1). The dithiolanes 7-10 and dithianes 11 and 12 (Scheme 2) were prepared by the condensations of 1,2-ethanedithiol and 1,3propanedithiol with the corresponding carbonyl compounds.

The screening reactions were carried out in simple shake flasks as described in the Experimental Section, and were monitored by GC (consumption of the starting materials) and TLC (appearance of the products). The bio-oxidations of functionalized dithianes and dithiolanes were found to be highly dependent on the individual substrate and bioreagent employed. The results are shown in Table 1. It should be pointed out that there are important differences in the way the two engineered microorganism function. Our previous experience has shown that $E$. coli/CHMO-catalyzed reactions are relatively rapid and a complete conversion (if a substrate is acceptable) is achieved within $24 \mathrm{~h}$. After $24 \mathrm{~h}$, fermentation and product formation essentially cease, and the products become contaminated with metabolites. For this reason, E. coli/CHMO reactions are rarely allowed to proceed for more than $48 \mathrm{~h}$. On the other hand, yeast/CHMO cells 
continue growing for a much longer period, and the formation of the products, although at a reduced rate, may continue for several days. The accompanying increase in metabolites complicates the purification but is compensated by increased yields.

Table 1. Screening of the substituted dithianes and dithiolanes as potential substrates for the engineered microorganisms expressing $\mathrm{CHMO}$

\begin{tabular}{|c|c|c|c|c|c|}
\hline & ${ }_{n S}^{-S} X_{R^{2}}^{R^{1}}$ & ${ }_{1 \mathrm{nS}}^{S^{\prime}} X_{\mathrm{R}^{2}}^{\mathrm{R}^{1}}$ & 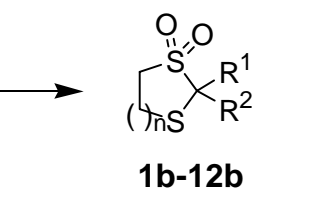 & $\begin{array}{l}R^{1}, R^{2} \text { cf. Scheme } 1 \text { and } \\
\text { structures listed below Sch } \\
n=1,2\end{array}$ & me 1. \\
\hline Compound & Biocatalyst & $\begin{array}{c}\text { Time } \\
{[\mathrm{h}]}\end{array}$ & $\begin{array}{c}\text { Starting material }^{\mathrm{a}} \\
{[\%]}\end{array}$ & $\begin{array}{c}\text { Sulfoxide a } \\
{[\%]^{\mathrm{b}} \text { (trans:cis) }}\end{array}$ & $\begin{array}{c}\text { Sulfone b } \\
{[\%]^{b}}\end{array}$ \\
\hline \multirow[t]{2}{*}{1} & Yeast/CHMO & 90 & $71^{\mathrm{c}}$ & -- & -- \\
\hline & E. coli/CHMO & 15 & 12 & $37(2: 1)$ & 10 \\
\hline \multirow[t]{2}{*}{2} & Yeast/CHMO & 130 & -- & $30-60(50: 1)$ & -- \\
\hline & E. coli/CHMO & 48 & $>90$ & -- & -- \\
\hline \multirow[t]{2}{*}{3} & Yeast/CHMO & 130 & -- & $33-60(19: 1)$ & -- \\
\hline & E.coli/CHMO & 48 & $>90$ & -- & -- \\
\hline \multirow[t]{2}{*}{4} & Yeast/CHMO & 130 & $>90$ & -- & -- \\
\hline & E. coli/CHMO & 48 & $>90$ & -- & -- \\
\hline \multirow[t]{2}{*}{5} & Yeast/CHMO & 130 & $>80$ & $>10$ & -- \\
\hline & E. coli/CHMO & nd & -- & -- & -- \\
\hline \multirow[t]{2}{*}{6} & Yeast/CHMO & 130 & $>90$ & -- & -- \\
\hline & E. coli/CHMO & -- & & & \\
\hline \multirow[t]{2}{*}{7} & Yeast/CHMO & 48 & 37 & $57(43: 1)$ & -- \\
\hline & E. coli/CHMO & 48 & 38 & $62(50: 1)$ & \\
\hline \multirow[t]{2}{*}{8} & Yeast/CHMO & 48 & 2 & $96(50: 1)$ & -- \\
\hline & E. coli/CHMO & 23 & 70 & $12(50: 1)$ & -- \\
\hline \multirow[t]{2}{*}{9} & Yeast/CHMO & 160 & 44 & $56(3: 1)$ & -- \\
\hline & E. coli/CHMO & 65 & nd & $50(3: 1)$ & \\
\hline 10 & Yeast/CHMO & 130 & 100 & -- & -- \\
\hline 11,12 & E. coli/CHMO & 130 & 100 & -- & -- \\
\hline
\end{tabular}

${ }^{a}$ GC results. ${ }^{b}$ Isolated yield after chromatography. ${ }^{c}$ Hydrolysis of the ester accounts for additional $17 \%$. nd $=$ not determined.

Compounds 4, 5, 6, 10, 11, and 12 were not transformed by either of the two microorganisms and were recovered unchanged after more than $130 \mathrm{~h}$ of fermentation. When compound 1 was incubated with the yeast reagent for $90 \mathrm{~h}$, there was no evidence of oxidation; the only reaction observed was hydrolysis of the ester. The recovered material was composed of $1(71 \%)$ and the 
corresponding acid (17\%). When the same material was transformed with E.coli, the product was a mixture of $\mathbf{1}(12 \%)$, $\mathbf{1 a}(37 \%)$, and $\mathbf{1 b}(10 \%)$. On the other hand, 2 and $\mathbf{3}$ on incubation with yeast/CHMO gave some product after approximately 5 days, but there was no evidence of any sulfoxide (or sulfone) production in the E. coli/CHMO-catalyzed transformations and most of the starting material could be recovered after fermentation for $48 \mathrm{~h}$. Compounds 7, 8, and 9 also showed promise as substrates for the recombinant strains.

Since the preliminary screening indicated 2, 3, 7, 8, and 9 as suitable candidates for the microorganism-catalyzed transformations, we re-investigated oxidations of these compounds. The goal was to establish enantioselectivity, diastereoselectivity, and to optimize yields. The results are shown in Table 2.

Table 2. Biooxidations of dithianes and dithiolanes

\begin{tabular}{|c|c|c|c|c|c|c|c|}
\hline & $\begin{array}{l}\int_{\mathrm{rS}}^{\mathrm{S}} \times_{\mathrm{R}^{2}}^{\mathrm{R}^{1}} \\
2,3,7-9\end{array}$ & & 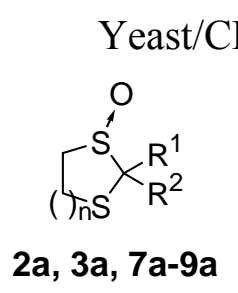 & $\begin{array}{l}\text { HMO } \\
\qquad \begin{array}{l}\mathrm{R}^{1}, \mathrm{R}^{2} \\
\text { structur } \\
\mathrm{n}=1,\end{array}\end{array}$ & $\begin{array}{l}\text { cf. Scheme } 1 \text { and } \\
\text { s listed below Sc }\end{array}$ & ne 1. & \\
\hline & & & & & Sulfoxide a & & \\
\hline $\begin{array}{l}\text { Starting } \\
\text { material }\end{array}$ & Biocatalyst & $\begin{array}{l}\text { Tim } \\
\mathrm{e}[\mathrm{h}]\end{array}$ & $\begin{array}{l}\text { Ratio }^{\mathrm{a}} \\
\text { material: sulf }\end{array}$ & $\begin{array}{l}\text { Starting } \\
\text { oxide a }\end{array}$ & $\begin{array}{l}\text { Yield [\%] } \\
\text { (trans:cis) }^{\mathrm{a}}\end{array}$ & $\begin{array}{l}\text { ee } \\
{[\%]}\end{array}$ & $\begin{array}{l}{[\alpha]_{\mathrm{D}}^{23}} \\
\left(\mathrm{CHCl}_{3}\right)\end{array}$ \\
\hline 2 & Yeast/CHMO & 200 & $36^{\mathrm{e}}$ & & $64(50: 1)$ & $\begin{array}{l}>99 \\
\mathrm{c}\end{array}$ & -75.4, c 3.1 \\
\hline 3 & Yeast/CHMO & 200 & $\mathrm{Nd}$ & & $63(19: 1)$ & $\begin{array}{l}>99 \\
\mathrm{c}\end{array}$ & -37.8 , c 6.6 \\
\hline 7 & $\begin{array}{l}\text { Yeast/CHMO } \\
\text { E. coli/CHMO }\end{array}$ & $\begin{array}{l}48 \\
48\end{array}$ & $\begin{array}{l}37: 63 \\
38: 62\end{array}$ & & $\begin{array}{l}51(43: 1) \\
22(50: 1)\end{array}$ & $\begin{array}{l}84^{d} \\
>99 \\
d\end{array}$ & $\begin{array}{l}\text { nd } \\
+38.1, \text { c } 1.5\end{array}$ \\
\hline 8 & $\begin{array}{l}\text { Yeast/CHMO } \\
\text { E. coli/CHMO }\end{array}$ & $\begin{array}{l}48 \\
23\end{array}$ & $\begin{array}{r}2: 98 \\
70: 30\end{array}$ & & $\begin{array}{l}96(50: 1) \\
12(50: 1)\end{array}$ & $36^{\mathrm{d}}$ & $\begin{array}{l}+11.2, \mathrm{c} 1.1 \\
\text { nd }\end{array}$ \\
\hline 9 & $\begin{array}{l}\text { Yeast/CHMO } \\
\text { E. coli/CHMO }\end{array}$ & $\begin{array}{r}160 \\
65 \\
\end{array}$ & $\begin{array}{l}44: 56 \\
45: 55 \\
\end{array}$ & & $\begin{array}{l}\text { nd }(3.5: 1) \\
50(3.5: 1)\end{array}$ & $\begin{array}{l}35^{\mathrm{d}} \\
\text { nd } \\
\text { nd }\end{array}$ & -5.64, c 1.5 \\
\hline
\end{tabular}

${ }^{a}$ From GC. ${ }^{b}$ Isolated yield after chromatography. ${ }^{\mathrm{c}}$ From chiral HPLC. ${ }^{\mathrm{d}}$ From chiral GC.

${ }^{\mathrm{e}}$ Recovered starting material. $\mathrm{nd}=$ not determined. 
Several controls were exercised to back-up biotransformations: (1) Chemical oxidations of the substrates were performed prior to biotransformations to establish methods for monitoring the reactions and to find suitable protocols for resolution of enantiomers and diastereomers. It turned out that products 2a and 3a could only be resolved on a chiral HPLC column, a process that took 80 minutes for each injection. The two reactions were followed by monitoring the consumption of dithianes $\mathbf{2}$ and 3; the products formation was confirmed by TLC. Only after the work-up the enantiomeric ratios were measured from chiral HPLC traces. The oxidations of the remaining three compounds $\mathbf{7 , 8}$, and $\mathbf{9}$ were followed by GC and chiral phase GC. The enantiopurity of sulfoxide 9a is not known because we were unable to obtain resolution on either chiral phase GC or chiral phase HPLC columns. (2) A small amount (5\%) of the natural substrate, cyclohexanone, was added together with the substrate in all reactions. Its prompt and complete conversion to caprolactone indicated that the normal cell growth and activity of yeast and E. coli was not inhibited by the substrates. (3) To establish that the native enzymes are not responsible for the oxidations, all starting materials were incubated with the carrier yeast and $E$. coli (in case of compounds $\mathbf{7}, \mathbf{8}$, and $\mathbf{9}$ ) and showed no evidence of any reaction.

In our efforts to optimize yields of sulfoxides, we discovered that the transformations of compounds $\mathbf{2}$ and $\mathbf{3}$ followed a different pattern from the oxidations of other sulfur-containing compounds. Whereas in all other fermentations, the formation of product would follow a relatively short lag period (typically a few hours) regardless of the rate of transformations, 2 and 3 remained unchanged for about 4 days. Only around the 5th day did the reaction start, as indicated by the consumption of the starting materials and the appearance of products. The reaction ceased after another $4-5$ days at approximately $65 \%$ conversion. Addition of supplemental fresh culture and longer incubation did not improve the conversions.

It is interesting to note that during microorganism-catalyzed fermentations of sulfides the $\mathrm{pH}$ generally remains at about 6.5 to 7 . In the course of the transformations of 2 and 3, however, there was no observable product formation in the early stages of the reaction when the $\mathrm{pH}$ was 6.5-7. After a 5-day fermentation the mixture spontaneously reached a $\mathrm{pH}$ of 8-9.5, at which stage the product started to appear. Maintaining the $\mathrm{pH}$ at 8.5 from the very beginning of the reaction did not change either its course or its outcome, while buffering the mixture to $\mathrm{pH} 7$ beyond the first 5 days prevented product formation entirely.

\section{Discussion}

Chiral sulfoxides derived from 1,3-dithianes and dithiolanes are valuable asymmetric building blocks and chiral auxiliaries for a wide range of organic reactions, ${ }^{22,}{ }^{23}$ but the preparation of these compounds in optically pure form is difficult. ${ }^{24}$ Bio-oxidations of simple 1,3-dithianes and dithiolanes ${ }^{5,8,12,16,17}$ demonstrated that CHMO from Acinetobacter is an important catalyst for this reactions, and our earlier studies, ${ }^{12}$ as well as the results presented in this paper, demonstrate that several such compounds, including very useful and highly interesting $\mathbf{2 a}$ and $\mathbf{3 a}$, can be 
prepared using the recombinant organisms overexpressing CHMO. Since the latter transformations do not involve pathogenic organisms and can be scaled up using optimized fermentation conditions, development of this route is very attractive. Furthermore, investigation of substituted dithiane and dithiolane substrates may contribute to better understanding of the active site and the oxidation mechanism of CHMO.

Several diastereotopic and enantiotopic preferences of the CHMO-catalyzed oxidations of 1,3-dithianes and dithiolanes emerged from initial studies with the isolated enzyme ${ }^{8}$ and Acinetobacter-mediated ${ }^{17}$ reactions. The absolute configurations of the unsubstituted dithiane and dithiolane were $(R)$-, and although the enantiomeric ratio (E value) ${ }^{25}$ for dithiane was a modest 20 , the product isolated was $>98 \%$ optically pure, due to the fact that CHMO oxidized the slower-forming $(S)$-enantiomer to sulfone more rapidly than it overoxidized its $(R)$-antipode. ${ }^{12}$ In the process, $(R)$ - was "purified" at the expense of the total yield of monosulfoxide. The oxidation of dithiolane was more selective with an E value of approximately $50{ }^{8}$ In 2-methyl substituted substrates the trans-products were predominantly favored (50:1) and the sulfoxides produced were the $(1 R, 2 R)$-isomers. In the case of the 2-(4-cyanophenyl)-substituted dithiolane the major sulfoxide formed was still trans (the absolute configuration was not established). The increasing steric bulk in 2,2-disubstituted substrates resulted in a decrease in yields and in the opposite $(S)$ configuration at sulfur, at least in the case of 2,2-dimethyl dithiane, for which the absolute configuration is known.

The enzyme CHMO has been shown to oxidize a large number of sulfides, generally in good yields and, in some cases, with a very high degree of enantioselectivity. ${ }^{5}$ Especially good results were obtained when one of the substituents on the sulfur was bulkier (alkyl or aryl) than the other (methyl or ethyl). ${ }^{18}$ On the basis of a large number of these reactions, Ottolina and coworkers developed a "cubic space" active site model. ${ }^{6}$ This model provides insight into the $(R)$ and $(S)$-selectivities in CHMO oxidations of para-substituted phenyl methyl sulfides ${ }^{9}$ and was extended, with some modifications, to explain enantio-preference in the Baeyer-Villiger reactions. $^{26}$ 

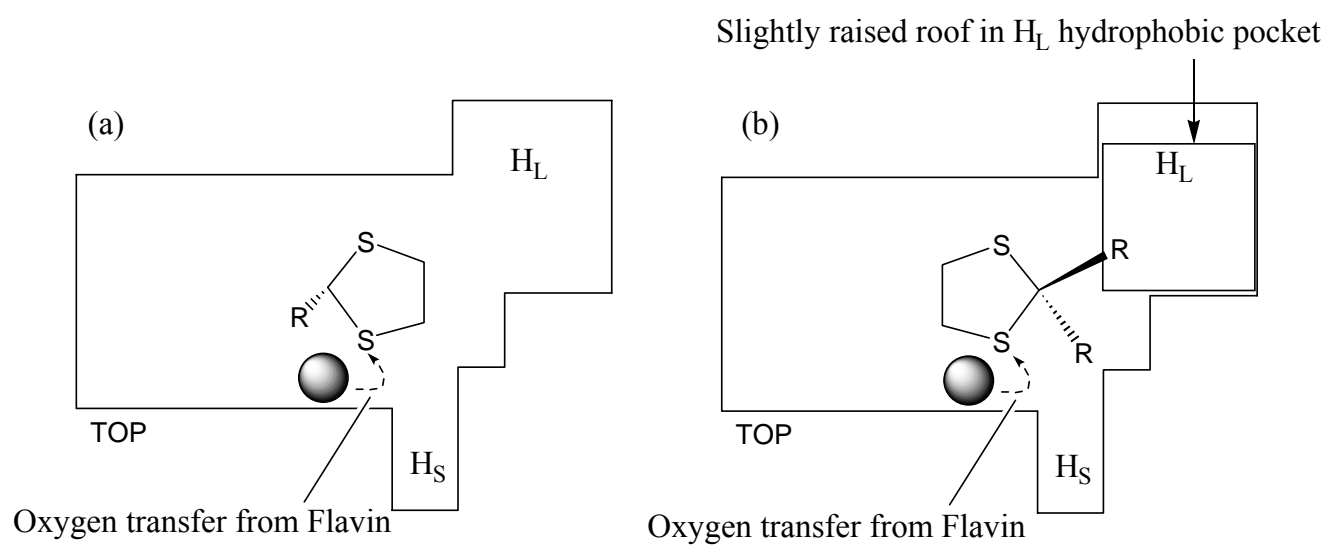

Oxygen transfer from Flavin

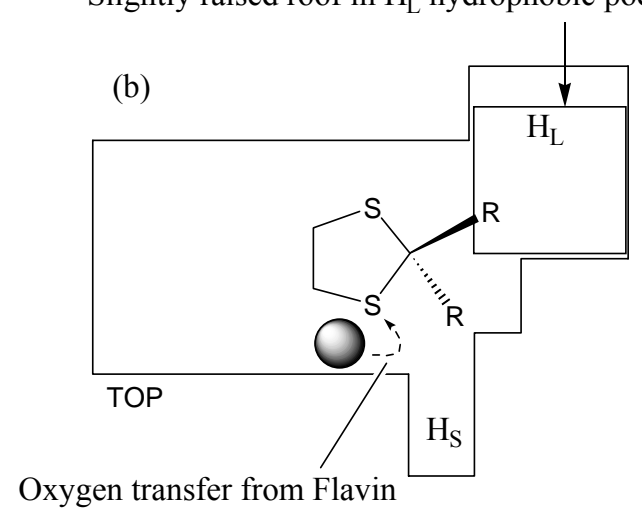

Figure 1. (a) Oxygen is transferred from the Flavin placed at the top of the "box." Dithiolane is positioned below Flavin in such a way as to allow the oxygen transfer from above. The nonreacting sulfur atom is placed in the $M$ (main) pocket. There is space below dithiolane but not much space above it; thus if there is a substituent in position 2 it should be trans to the incoming oxygen atom. The oxygen transfer results in formation of the $(R)$ enantiomer and trans $(R, R)$ diastereomer. (b) This model may also explain why the 2,2-disubstituted substrates do not fit in the same way and why 2,2-dimethyl dithiolane gives $(S)$ sulfoxide, while our 2,2-disubstituted compounds $\mathbf{1 0}$ and $\mathbf{1 1}$ are not acceptable substrates for CHMO. In the case of the latter substrates one of the $\mathrm{R}$ groups points out toward the "top" of the box model. The only space available above is in the HL box which has roof slightly raised over the main body of the box.

It is possible to explain the absolute configurations of the sulfoxides from the CHMO oxidations of these 1,3-dithioacetals in terms of the active site model discussed above. ${ }^{6,8}$ Placing the "non-oxidized" sulfur atom in the M (main) pocket of the model and transferring oxygen from the Flavin located at the top to the "sulfur-to-be-oxidized", as proposed by the authors, leads to the $(R)$-enantiomer (Figure 1$)$. The more rapid oxidation of the minor $(S)$-sulfoxide to sulfone is in agreement with this interpretation and so are the results obtained in the oxidation of 2-alkyl substituted compounds $\mathbf{7}$ and $\mathbf{8}$ included in this study. The absolute configuration obtained in the oxidation of 2,2-dimethyldithiane, the poor acceptance of the 2,2-disubstituted substrates with bulkier substituents by isolated enzymes, and a failure to oxidize compounds $\mathbf{1 0}$, 11, and 12 can also be explained in terms of the active site model.

A still unresolved "mystery" is the successful oxidation of compounds $\mathbf{2}$ and $\mathbf{3}$. The very long lag times are puzzling. It is well known that $\mathrm{pH} 8.6$ is optimal for the performance of the CHMO enzyme. However, buffering the reaction at $\mathrm{pH} 8$ did not shorten the lag period. It appears that it is only at the stationary phase, when the yeast cells start to die, that the reaction occurs. This could explain why the product yields are relatively low (maximum 64\% obtained), since under these conditions the availability and recycling of NADPH, which is critical in this reaction, may have "run out". Another intriguing question is why the recombinant E. coli system did not yield any product even after the similarly long incubation periods. We are presently addressing these 
questions.

In conclusion, it is important to recognize that recombinant yeast and E. coli strains overexpressing cyclohexanone monooxygenase are useful reagents for the oxidation of a range of dithiane and dithiolane substrates. It is clear that preliminary screening and control experiments are needed when significantly altered substrates are considered. Absence of competing activity from native oxidizing enzymes of the host strains must also be established. However, the final pay-off is often worth the preliminary work since it may provide a direct route to highly desirable, optically pure or highly enriched compounds such as sulfoxides $\mathbf{2 a}$ and 3a, which are difficult and cumbersome to prepare via conventional chemical approaches. Furthermore, the fermentation can be scaled-up and optimized thus giving access to large quantities of these useful products. From a mechanistic point of view, the unraveling of the processes occurring during the CHMO-catalyzed oxidation of the substrates $\mathbf{2}$ and $\mathbf{3}$ may throw some additional light on the active site and the behavior of the important and widely employed cyclohexanone monooxygenase enzyme.

\section{Experimental Section}

General Procedures. NMR spectra were obtained on Brucker AMX 400 or on Varian XL-200. All spectra were recorded in $\mathrm{CDCl}_{3}$ solutions with TMS as the internal standard unless otherwise specified. IR spectra from thin films were recorded on a Nicolet 520 FT-IR spectrophotometer or a Perkin Elmer 297 instrument. Optical rotations were measured on a Perkin-Elmer 241 polarimeter operating at room temperature. HPLC was performed on a Beckman System Gold personal chromatograph using an Econosphere $4.6 \mathrm{~mm} \times 250 \mathrm{~mm} \times 5 \mathrm{~m}$ Silica-C18 column (Alltech) coupled with a $4.6 \mathrm{~mm} \times 150 \mathrm{~mm} \times 5 \mu \mathrm{m}$ Chiralcel OD-H column (Daicel Chemical Industries Ltd.) operated at room temperature. Mixtures of hexanes and 2-propanol were used as the mobile phase. Capillary gas chromatography were performed on a Shimatzu GC-9A or HP 5890 gas chromatograph utilizing a DB-1301 $0.54 \mu \mathrm{m} \times 1.0 \mathrm{~mm} \times 15 \mathrm{~m}$ column $(\mathrm{J} \& \mathrm{~W})$ or a $\beta$ $\mathrm{CD}-2250.32 \mathrm{~mm} \times 30 \mathrm{~m} \times 0.25 \mu \mathrm{m}$ column (Supelco) and helium as the carrier gas. The injector and detector temperatures were maintained at $225^{\circ} \mathrm{C}$ and $300{ }^{\circ} \mathrm{C}$ respectively. Thin-layer chromatography was performed on pre-coated silica gel 60 plates (Whatmann). Flash chromatography separations were conducted on 200-425 mesh silica gel (Silicycle/Merck. All solvents were dried and purified by fractional distillation. Other reagents were obtained from commercial suppliers and used as received.

\section{General procedure A for synthesizing dithiolanes and dithianes ${ }^{27}$}

The aldehyde or ketone $(20 \mathrm{mmol})$ and 1,2-ethanedithiol $(1.7 \mathrm{~mL}, 20 \mathrm{mmol})$ were dissolved in $\mathrm{CH}_{2} \mathrm{Cl}_{2}(40 \mathrm{~mL})$. The solution was cooled in an ice-water bath, and $\mathrm{BF}_{3} \cdot \mathrm{Et}_{2} \mathrm{O}(1 \mathrm{~mL})$ was added dropwise. After the addition, the ice-bath was removed and the reaction mixture was vigorously stirred at room temperature for $1 \mathrm{~h}$. The mixture was poured into a mixture of saturated $\mathrm{NaHCO}_{3}$ 
$(40 \mathrm{~mL})$ and ice, the organic layer was washed thoroughly with saturated $\mathrm{NaHCO}_{3}$, and the aqueous phase was extracted with $\mathrm{CH}_{2} \mathrm{Cl}_{2}$. The combined organic phase was dried over anhydrous $\mathrm{MgSO}_{4}$ and the solvent was removed on a rotary evaporator. The residue was purified when necessary by vacuum distillation or flash chromatography on silica gel using mixtures of hexane and ethyl acetate as the eluent to give the final product. Dithianes were synthesized in a similar manner using 1,3-propanedithiol.

\section{General procedure B for synthesizing 2-functionalized [1, 3]dithianes (2-6)}

$\mathrm{NaH}$ (50\% dispersion in mineral oil) was placed in a $100 \mathrm{~mL} 3$-neck round bottom flask equipped with a refluxing condenser, a pressure equalizing dropping funnel, and a nitrogen balloon. The system was flushed 3 times with nitrogen, and $\mathrm{NaH}$ was washed 3 times with THF. A solution of ethyl [1,3]dithiane-2-carboxylate $(\mathbf{1}, 1.92 \mathrm{mg}, 10 \mathrm{mmol})$ in THF $(20 \mathrm{~mL})$ was added and the stirred mixture was heated to $70{ }^{\circ} \mathrm{C}$ until homogeneous. After cooling in an icewater bath an appropriate electrophile $(10 \mathrm{mmol})$ in THF $(20 \mathrm{~mL})$ was added slowly with vigorous stirring. In some cases, the stirred reactions required further heating. When the reaction had finished (as monitored by GC) the mixture was poured into ice water and extracted with ethyl acetate in 3 portions (total of $100 \mathrm{~mL}$ ). The combined extracts were dried over anhydrous $\mathrm{Na}_{2} \mathrm{SO}_{4}$, and the solvent was removed on a rotary evaporator. The residue was purified by flash chromatography using a mixture of petroleum ether/ethyl acetate as eluent.

Ethyl [1,3]dithiane-2-carboxylate (1). ${ }^{28}$ Compound 1 (Aldrich) was prepared on a several gram scale according to General Procedure A.

Ethyl 2-(2-methoxyethyl)[1,3]dithiane-2-carboxylate (2). ${ }^{29} \mathrm{NaH}$ (1 g, $\left.20 \mathrm{mmol}\right), 1$ (1.92 g in $10 \mathrm{~mL}$ THF, $10 \mathrm{mmol})$ and 2-bromoethyl methyl ether $(2.0 \mathrm{~g}$ in $10 \mathrm{~mL}$ THF, $16 \mathrm{mmol})$ reacted at $50{ }^{\circ} \mathrm{C}$ for $4 \mathrm{~h}$ according to General Procedure B. The mixture was poured into distilled water and the $\mathrm{pH}$ was adjusted to 2 with $2 \mathrm{M} \mathrm{HCl}$. The mixture was extracted with petroleum ether in 3 portions (total of $100 \mathrm{~mL}$ ). The combined extracts were dried over anhydrous $\mathrm{MgSO}_{4}$ and the solvent was removed under reduced pressure. Flash chromatography using petroleum ether/ethyl acetate (8:1) as eluent gave $2(1.75 \mathrm{~g}, 70 \%)$ as light yellow oil. IR (neat): $\widetilde{v} 2990,2840,2900$, 2840, 2820, 1730, 1420, 1220, 1115, $1020 \mathrm{~cm}^{-1}$; ${ }^{1} \mathrm{H}$ NMR (400 MHz, $\left.\mathrm{CDCl}_{3}\right): \delta 4.25(2 \mathrm{H}, \mathrm{q}, J=$ $7.0 \mathrm{~Hz}), 3.60(2 \mathrm{H}, \mathrm{t}, J=7.0 \mathrm{~Hz}), 3.31(3 \mathrm{H}, \mathrm{s}), 3.30(2 \mathrm{H}, \mathrm{td}, J=12.2,2.75 \mathrm{~Hz}), 2.67(2 \mathrm{H}, \mathrm{t}, J=6.7$ $\mathrm{Hz}), 2.15(1 \mathrm{H}, \mathrm{m}), 1.87(1 \mathrm{H}, \mathrm{m}), 1.33(3 \mathrm{H}, \mathrm{t}, J=7.0 \mathrm{~Hz}) ;{ }^{13} \mathrm{C} \mathrm{NMR}\left(100.5 \mathrm{MHz}, \mathrm{CDCl}_{3}\right): \delta$ $171.0,68.1,61.9,60.4,58.8,38.2,27.8,24.6,14.2$.

Ethyl 2-(ethoxymethyl)[1,3]dithiane-2-carboxylate (3). NaH (4 g, excess), chloromethyl ethyl ether $(3 \mathrm{~mL}, 32 \mathrm{mmol})$, and a solution of $1(3.84 \mathrm{~g}, 20 \mathrm{mmol})$ in THF $(20 \mathrm{~mL})$ reacted at reflux for $1 \mathrm{~h}$ according to General Procedure B. The crude product was purified by flash chromatography using petroleum ether/acetone (10:1) as eluent to give $3(3.57 \mathrm{~g}, 71 \%)$ as a colorless oil. IR (neat): $\widetilde{v} 2973,2934,2901,2868,1729,1440,1229,1117,1071,1091 \mathrm{~cm}^{-1} ;{ }^{1} \mathrm{H}$ NMR (400 MHz, $\left.\mathrm{CDCl}_{3}\right): \delta 4.22(2 \mathrm{H}, \mathrm{q}, J=7.0 \mathrm{~Hz}), 3.77(2 \mathrm{H}, \mathrm{s}), 3.52(2 \mathrm{H}, \mathrm{q}, J=7.0 \mathrm{~Hz}), 3.20$ $(2 \mathrm{H}, \mathrm{ddd}, J=14.5,11.8,2.7 \mathrm{~Hz}), 2.65(2 \mathrm{H}, \mathrm{ddd}, J=14.4,5.0,3.2 \mathrm{~Hz}), 2.09$ (1H, multiplet of 13 
peaks), $1.92-1.79(1 \mathrm{H}, \mathrm{m}), 1.27(3 \mathrm{H}, \mathrm{t}, J=7.2 \mathrm{~Hz}), 1.13(3 \mathrm{H}, \mathrm{t}, J=7.0 \mathrm{~Hz}) ;{ }^{13} \mathrm{C}$ NMR $(100.5$ $\left.\mathrm{MHz}, \mathrm{CDCl}_{3}\right): \delta 170.0,74.5,67.4,61.8,53.0,27.0,24.7,14.7,14.0$.

Ethyl 2-(n-butyl)[1,3]dithiane-2-carboxylate (4). ${ }^{30} \mathrm{NaH}$ (0.8 g, excess), 1 (1.92 g, 10 mmol), and $n-\mathrm{BuI}(2 \mathrm{~mL}$, excess) reacted at room temperature overnight according to General Procedure B to give $4(1.78 \mathrm{~g}, 72 \%)$ as a pale yellow oil. IR (neat): $\widetilde{v} 2960,2930,2870,1725,1465,1420$, 1240, 1200, 1120, $1025 \mathrm{~cm}^{-1}$; ${ }^{1} \mathrm{H}$ NMR (400 MHz, $\left.\mathrm{CDCl}_{3}\right): \delta 4.20(2 \mathrm{H}, \mathrm{q}, J=7.2 \mathrm{~Hz}), 3.24(2 \mathrm{H}$, m), $2.60(2 \mathrm{H}$, ddd, $J=14.3,4.3,3.2 \mathrm{~Hz}), 2.1(1 \mathrm{H}, \mathrm{dm}, J=14.0 \mathrm{~Hz}), 1.96-1.91(2 \mathrm{H}, \mathrm{m}), 1.87-$ $1.71(2 \mathrm{H}, \mathrm{m}), 1.46-1.33(2 \mathrm{H}, \mathrm{m}), 1.28(1 \mathrm{H}, \mathrm{t}, J=7.7 \mathrm{~Hz}), 1.27(3 \mathrm{H}, \mathrm{t}, J=7.2 \mathrm{~Hz}), 0.85(3 \mathrm{H}, \mathrm{t}, J$ $=7.5 \mathrm{~Hz}) ;{ }^{13} \mathrm{C} \mathrm{NMR}\left(100.5 \mathrm{MHz}, \mathrm{CDCl}_{3}\right): \delta 170.9,61.6,52.6,38.6,27.8,26.4,24.7,22.8,14.1$, 13.7.

Ethyl 2-(2-cyanoethyl)[1,3]dithiane-2-carboxylate (5). NaH (1 g, 20 mmol), 1 (1.92 g, 10 mmol) and a solution of acrylonitrile $(1 \mathrm{~mL}, 15 \mathrm{mmol})$ in THF $(10 \mathrm{~mL})$ reacted at $0{ }^{\circ} \mathrm{C}$ for 30 min according to General Procedure B. The product was purified by flash chromatography using petroleum ether/ethyl acetate (8:1) as eluent to give $5(1.24 \mathrm{~g}, 51 \%)$ as a colorless oil. IR (neat): $\widetilde{v} 2980,2934,2894,2829,2256,1736,1427,1223,1183,1052 \mathrm{~cm}^{-1} ;{ }^{1} \mathrm{H}$ NMR $(200 \mathrm{MHz}$, $\left.\mathrm{CDCl}_{3}\right): \delta 4.28(2 \mathrm{H}, \mathrm{q}, J=7.0 \mathrm{~Hz}), 3.35(2 \mathrm{H}, \mathrm{m}), 2.77-2.62(4 \mathrm{H}, \mathrm{m}), 2.38(2 \mathrm{H}, \mathrm{t}, J=8.9 \mathrm{~Hz})$, $2.18(1 \mathrm{H}, \mathrm{m}), 1.74(1 \mathrm{H}, \mathrm{m}), 1.35(3 \mathrm{H}, \mathrm{t}, J=7.0 \mathrm{~Hz}) ;{ }^{13} \mathrm{C} \mathrm{NMR}\left(50.3 \mathrm{MHz}, \mathrm{CDCl}_{3}\right): \delta 170.0$, $119.1,62.2,60.3,33.8,27.5,24.0,14.1,13.0$.

2-Oxa-6,10-dithiaspiro[4.5]decan-1-one (6). $\mathrm{NaH}(0.5 \mathrm{~g}, 50 \%$ dispersion in mineral oil, 10 $\mathrm{mmol}$ ) was placed in a $100 \mathrm{~mL} 3$-neck round bottom flask equipped with a pressure equalizing dropping funnel and a nitrogen inlet tube. The system was flushed with nitrogen, and the $\mathrm{NaH}$ was washed 3 times with THF. A solution of $1(1.92 \mathrm{~g}, 10 \mathrm{mmol})$ in THF $(20 \mathrm{~mL})$ was added, and the flask was heated to $35-40{ }^{\circ} \mathrm{C}$ for 20 min until a homogeneous gray-green suspension was obtained. $\mathrm{NaH}(0.8 \mathrm{~g}, 50 \%$ dispersion in mineral oil, $17 \mathrm{mmol})$ was placed in another $50 \mathrm{~mL} \mathrm{3-}$ neck round bottom flask equipped with a pressure equalizing dropping funnel and a nitrogen balloon; the system was flushed 3 times with nitrogen and the $\mathrm{NaH}$ was washed 3 times with THF. Freshly distilled THF $(10 \mathrm{~mL})$ was added and the flask was cooled to $-15^{\circ} \mathrm{C}$ in an ice-salt bath. A solution of 2-bromoethanol $(1.25 \mathrm{~g}, 10 \mathrm{mmol})$ in THF $(50 \mathrm{~mL})$ was added slowly. After stirring at $-15^{\circ} \mathrm{C}$ for $30 \mathrm{~min}$, this solution was transferred to the first flask via cannula at $-15^{\circ} \mathrm{C}$ during a period of $5 \mathrm{~min}$. The flask was maintained at $-15{ }^{\circ} \mathrm{C}$ to $0{ }^{\circ} \mathrm{C}$ for $30 \mathrm{~min}$, then it was warmed up to room temperature during $30 \mathrm{~min}$. The mixture was poured into ice-water and extracted with ether in 3 portions (total of $100 \mathrm{~mL}$ ). The solvent was removed under reduced pressure, and the residue was purified by flash chromatography using petroleum ether/ethyl acetate (8:1) as eluent to give $\mathbf{6}(1.59 \mathrm{~g}, 83 \%)$ as pale yellow oil. IR (neat): $\widetilde{v} 2987,2934,1736$, $1295,1144,1032 \mathrm{~cm}^{-1}$; ${ }^{1} \mathrm{H}$ NMR (400 MHz, $\left.\mathrm{CDCl}_{3}\right): \delta 4.16(2 \mathrm{H}, \mathrm{q}, J=6.8 \mathrm{~Hz}), 3.34(2 \mathrm{H}, \mathrm{ddd}, J$ $=14.0,11.2,2.8 \mathrm{~Hz}), 2.54(2 \mathrm{H}, \mathrm{ddd}, J=13.6,5.6,3.2 \mathrm{~Hz}), 2.07(1 \mathrm{H}, \mathrm{m}), 1.96(1 \mathrm{H}, \mathrm{m}), 1.25$ $(2 \mathrm{H}, \mathrm{t}, J=6.8 \mathrm{~Hz}) ;{ }^{13} \mathrm{C} \mathrm{NMR}\left(100.5 \mathrm{MHz}, \mathrm{CDCl}_{3}\right): \delta 169.7,61.5,60.2,39.9,25.8,24.9,13.9$.

2-Isobutyl[1,3]dithiolane (7). ${ }^{31}$ Isovaleraldehyde $(1.72 \mathrm{~g}, 20 \mathrm{mmol})$ and 1,2-ethanedithiol $(1.7$ $\mathrm{mL}, 20 \mathrm{mmol})$ reacted according to General Procedure A. Vacuum distillation $\left(100-110{ }^{\circ} \mathrm{C} / 3\right.$ mmHg) gave 7 (2.82 g, 87\%) as colorless oil. IR $v_{\max }$ (neat): $\widetilde{v} 2960,2927,2868,1466,1367$, 
1275, 1176, 854, $755 \mathrm{~cm}^{-1} ;{ }^{1} \mathrm{H}$ NMR (400 MHz, $\left.\mathrm{CDCl}_{3}\right): \delta 4.53(1 \mathrm{H}, \mathrm{t}, J=1.3 \mathrm{~Hz}$ ), 3.26-3.13 $(4 \mathrm{H}, \mathrm{m}), 1.72-1.68(3 \mathrm{H}, \mathrm{m}), 0.92-0.90(6 \mathrm{H}, \mathrm{d}, J=6.8 \mathrm{~Hz}) ;{ }^{13} \mathrm{C}$ NMR $\left(100.5 \mathrm{MHz}, \mathrm{CDCl}_{3}\right): \delta$ $51.9,48.1,38.2,28.4,22.3$.

2-Pentyl[1,3]dithiolane (8). ${ }^{32}$ Hexanal $(2 \mathrm{~g}, 20 \mathrm{mmol})$ and 1,2-ethanedithiol $(1.7 \mathrm{~mL}, 20 \mathrm{mmol})$ reacted according to General Procedure A. Vacuum distillation $\left(100-110^{\circ} \mathrm{C} / 1 \mathrm{mmHg}\right)$ gave 8 $(2.68 \mathrm{~g}, 76 \%)$ as colorless oil. ${ }^{1} \mathrm{H}$ NMR $\left(400 \mathrm{MHz}, \mathrm{CDCl}_{3}\right): \delta 4.42(1 \mathrm{H}, \mathrm{t}, J=3.6 \mathrm{~Hz}), 3.19$ $(4 \mathrm{H}, \mathrm{m}), 1.78(2 \mathrm{H}, \mathrm{q}, J=4.0 \mathrm{~Hz}), 1.40(2 \mathrm{H}, \mathrm{q} J=3.96 \mathrm{~Hz}), 1.27(4 \mathrm{H}, \mathrm{m}), 0.84(3 \mathrm{H}, \mathrm{t}, J=3.2$ $\mathrm{Hz}) ;{ }^{13} \mathrm{C} \mathrm{NMR}\left(100.5 \mathrm{MHz}, \mathrm{CDCl}_{3}\right): \delta 53.8,39.2,38.2,31.3,28.9,22.4,13.9$.

Ethyl 2-methyl[1,3]dithiolane-2-carboxylate (9). ${ }^{33}$ Ethyl acetoacetate $(1.5 \mathrm{~mL}, 20 \mathrm{mmol})$ and 1,2-ethanedithiol $(1.7 \mathrm{~mL}, 20 \mathrm{mmol})$ reacted according to General Procedure A. The mixture was extracted with $\mathrm{CH}_{2} \mathrm{Cl}_{2}$ in 3 portions (total of $120 \mathrm{~mL}$ ). The combined extracts were dried over anhydrous $\mathrm{MgSO}_{4}$ and the solvent was removed under reduced pressure. The residue was purified by flash chromatography using petroleum ether/ethyl acetate (20:1) as eluent to give $\mathbf{9}$ $(4.0 \mathrm{~g}, 93.2 \%)$ as light yellow oil. IR (neat): $\widetilde{v} 2979,2924,1736,1336,1187,1087 \mathrm{~cm}^{-1} ;{ }^{1} \mathrm{H}$ NMR (400 MHz, $\left.\mathrm{CDCl}_{3}\right): \delta 4.09(2 \mathrm{H}, \mathrm{q}, J=3.6 \mathrm{~Hz}), 3.25-3.35(4 \mathrm{H}, \mathrm{m}), 2.95(2 \mathrm{H}, \mathrm{s}), 1.85$ $(3 \mathrm{H}, \mathrm{s}), 1.22(3 \mathrm{H}, \mathrm{t}, J=3.4) ;{ }^{13} \mathrm{C} \mathrm{NMR}\left(100.5 \mathrm{MHz}, \mathrm{CDCl}_{3}\right): \delta 169.9,62.1,60.4,50.1,39.7$, 31.5, 14.0.

2,2-Dibutyl-[1,3]dithiolane (10). Dibutyl ketone (2.84 g, $20 \mathrm{mmol})$ and 1,2-ethanedithiol $(1.7 \mathrm{~mL}, 20 \mathrm{mmol})$ reacted according to General Procedure A. Vacuum distillation (110 ${ }^{\circ} \mathrm{C} / 0.1 \mathrm{mmHg}$ ) gave $\mathbf{1 0}(3.95 \mathrm{~g}, 91 \%)$ as a colorless oil. IR (neat): $\widetilde{v}$ 2956.2, 2930.9, 2859.2, 1464.1, 1378.1, $1276.3 \mathrm{~cm}^{-1}$; ${ }^{1} \mathrm{H}$ NMR (400 MHz, $\left.\mathrm{CDCl}_{3}\right): \delta 3.27(4 \mathrm{H}, \mathrm{s}), 1.91(4 \mathrm{H}, \mathrm{m}), 1.44$ $(4 \mathrm{H}, \mathrm{m}), 1.34(4 \mathrm{H}, \mathrm{m}), 0.93(6 \mathrm{H}, \mathrm{t}, J=5.5 \mathrm{~Hz}) ;{ }^{13} \mathrm{C} \mathrm{NMR}\left(100.5 \mathrm{MHz}, \mathrm{CDCl}_{3}\right): \delta 71.6,43.2$, $39.3,29.1,22.9,14.0$.

2-Isobutyl[1,3]dithiane (11) ${ }^{34}$ and ethyl 2-methyl[1,3]dithiane-2-carboxylate (12) ${ }^{35}$ were prepared as above and their spectroscopic data were consistent with those reported previously.

\section{General procedure $C$ for yeast-mediated oxidations ${ }^{10,12}$}

Propagation and maintenance of the yeast reagent have been described before. ${ }^{10}$ YPG medium $(100 \mathrm{~mL}, 1 \%$ bacto-yeast extract, $2 \%$ bacto-peptone, $2 \%$ galactose) was added to a $250 \mathrm{~mL}$ baffled Erlenmeyer flask, followed by substrate $(100 \mu \mathrm{L})$, cyclohexanone $(3 \mu \mathrm{L})$, frozen yeast cells $(0.2 \mathrm{~g})$ and $\gamma$-cyclodextrin $(0.5 \mathrm{~g})$. The reaction mixture was shaken at $30{ }^{\circ} \mathrm{C}, 250 \mathrm{rpm}$. The reaction was monitored by GC and/or Chiral-GC until complete disappearance of starting material was shown, or there was no observable change in the relative concentrations of starting material, standard, and product. At this point, the reaction mixture was centrifuged $(3000 \mathrm{~g})$ at $4{ }^{\circ} \mathrm{C}$ for $10 \mathrm{~min}$ to remove yeast cells. The supernatant layer was saturated with $\mathrm{NaCl}$ and extracted with ethyl acetate $(100 \mathrm{~mL} \times 3)$. The combined organic extracts were washed once with brine, dried $\left(\mathrm{Na}_{2} \mathrm{SO}_{4}\right)$ and concentrated under reduced pressure. The residue was purified by flash chromatography on silica gel. 


\section{General procedure $D$ for $E$. coli-mediated reactions ${ }^{12}$}

Propagation and maintenance of $E$. coli strains have been described before. ${ }^{12}$ The E. coli strain BL21(DE3)(pMM04) was streaked from a frozen stock on LB-Ampicillin plates and incubated at $37^{\circ} \mathrm{C}$ until colonies were $1-2 \mathrm{~mm}$ in size. One colony was used to inoculate an LB-Ampicillin medium $(10 \mathrm{~mL})$ in a $50 \mathrm{~mL}$ Erlenmeyer flask and incubated at $37^{\circ} \mathrm{C}, 250 \mathrm{rpm}$ overnight This culture was used at a 1:100 ratio to inoculate an LB-Ampicillin medium supplemented with 10\% glucose in a baffled Erlenmeyer flask. The culture was incubated at $30^{\circ} \mathrm{C}, 250 \mathrm{rpm}$ until $\mathrm{OD}_{600}$ was approximately 1 . Isopropyl- $\beta$-thio-D-galactoside (IPTG) stock solution $(1.0 \mathrm{M})$ was added $(0.1 \mu \mathrm{L}$ per $\mathrm{mL}$ of medium) followed by the substrate. If cyclodextrin was necessary to alleviate the solubility problem, it was introduced at this stage. The culture was agitated at room temperature at $250 \mathrm{rpm}$ and monitored by GC, HPLC, or TLC until the starting material disappeared, or there was no observable change in the relative concentrations of starting material, standard, and product. The culture was saturated with $\mathrm{NaCl}$ and extracted with ethyl acetate. Combined extracts were washed once with brine and dried $\left(\mathrm{Na}_{2} \mathrm{SO}_{4}\right.$ or $\left.\mathrm{MgSO}_{4}\right)$. The solvent was removed under reduced pressure, and the residue was purified by flash chromatography.

\section{General procedure $\mathbf{E}$ for chemical oxidations ${ }^{36}$}

A solution of dithiane or dithiolane $(10 \mathrm{mmol})$ in methanol $(50 \mathrm{~mL})$ was cooled to approximately $15^{\circ} \mathrm{C} . \mathrm{NaIO}_{4}(2.35 \mathrm{~g}, 11 \mathrm{mmol})$ was dissolved in warm water $(10 \mathrm{~mL})$ and added to the solution of dithiane at $15{ }^{\circ} \mathrm{C}$ at a rate that kept the reaction temperature below $20{ }^{\circ} \mathrm{C}$. The reaction was stirred at room temperature for 30-90 min until TLC analysis showed a complete consumption of the starting material. The mixture was evaporated to near dryness, the residue was diluted with distilled water and extracted with ethyl acetate. The combined organic extracts were dried over $\mathrm{Na}_{2} \mathrm{SO}_{4}$ and concentrated under reduced pressure. Pure products were obtained by flash chromatography on silica gel.

Ethyl [1,3]dithiane-2-carboxylate 1-oxide (1a). Ethyl [1,3]dithiane-2-carboxylate (1, $100 \mu \mathrm{L}$, $0.52 \mathrm{mmol})$ was oxidized by yeast in the presence of $\gamma$-cyclodextrin $(0.5 \mathrm{~g})$. The product was purified by chromatography using petroleum ether/acetone $(3: 1)$, followed by acetone as eluents. The recovered material was a mixture of 1 (79 mg, 77\%) and 1,3-dithiane-2-carboxylic acid (19 mg, 17\%). IR (neat): $\widetilde{v} 3085,3026,2980,2829,2690,2578,1703,1414,1308,1177,927 \mathrm{~cm}^{-1}$; ${ }^{1} \mathrm{H}$ NMR (400 MHz, $\left.\mathrm{CDCl}_{3}\right): \delta 4.17(1 \mathrm{H}, \mathrm{s}), 3.42(2 \mathrm{H}, \mathrm{m}), 2.60(2 \mathrm{H}, \mathrm{m}), 2.25-1.93(2 \mathrm{H}, \mathrm{m}) ;{ }^{13} \mathrm{C}$ $\mathrm{NMR}\left(100.5 \mathrm{MHz}, \mathrm{CDCl}_{3}\right): \delta 176.1,39.2,25.6,24.7$.

E. coli-mediated oxidation of $1(100 \mu \mathrm{L})$ according to General Procedure D gave 1a (40 mg, $37 \%$ ) as a yellow oil. NMR indicated a mixture of cis/trans-isomers; spectroscopic data were recorded from the mixture. IR $v_{\max }$ (neat): $\widetilde{v} 2987,2927,1736,1427,1315,1262,1163,1052$, $867 \mathrm{~cm}^{-1} ;{ }^{1} \mathrm{H}$ NMR (400 MHz, $\mathrm{CDCl}_{3}$ ): $\delta 4.29$ (1H, br, two overlapping singlets), 4.27 (2H, two overlapping sets of quartets, $J=7.2 \mathrm{~Hz}), 3.55(1 \mathrm{H}, \mathrm{td}, J=12.5,2.7 \mathrm{~Hz}), 3.35(1 \mathrm{H}$, multiplet of 16 peaks), 3.22 $(1 \mathrm{H}$, multiplet of 7 peaks $), 3.01(1 \mathrm{H}, \mathrm{m}), 2.80(2 \mathrm{H}, \mathrm{m}), 2.64-2.42(3 \mathrm{H}, \mathrm{m}), 2.32(1 \mathrm{H}$, $\mathrm{dt}, J=14.0,4.8 \mathrm{~Hz}), 2.26-2.17(1 \mathrm{H}, \mathrm{m}), 2.17-2.04(1 \mathrm{H}, \mathrm{m}) ;{ }^{13} \mathrm{C} \mathrm{NMR}\left(100.5 \mathrm{MHz}, \mathrm{CDCl}_{3}\right): \delta$ 
$166.1,165.7,64.3,62.9,55.3,50.4,46.5,28.0,26.4,24.2,14.1,13.9$. Chemical oxidation of $\mathbf{1}$ (1.92 g, $10 \mathrm{mmol})$ according to General Procedure E gave a mixture of steroisomers. Flash chromatography using petroleum ether/acetone (2:1) as eluent gave 1a (1.54 g, 74\%) as oil, which solidified upon standing.

Ethyl 2-(2-methoxyethyl)[1,3]dithiane-2-carboxylate 1-oxide (2a). Dithiane 2 (200 $\mu \mathrm{L}$, $0.86 \mathrm{mmol}$ ) was oxidized by yeast according to General Procedure C. The product was purified by chromatography using petroleum ether/ethyl acetate (4:1) as eluent to give starting material 2 (74 mg, 37\%) and sulfoxide 2a (130 mg, 61\%) as a colorless oil. IR (neat): $\widetilde{v}$ 2993, 2927, 2815, 1723, 1229, 1124, $1038 \mathrm{~cm}^{-1}$; ${ }^{1} \mathrm{H}$ NMR (400 MHz, $\left.\mathrm{CDCl}_{3}\right): \delta 4.40-4.28(2 \mathrm{H}, \mathrm{m}), 3.66-3.60$ $(2 \mathrm{H}, \mathrm{m}), 3.32(3 \mathrm{H}, \mathrm{s}), 3.31-3.21(2 \mathrm{H}, \mathrm{m}), 3.13-3.06(1 \mathrm{H}, \mathrm{m}), 2.85-2.75(1 \mathrm{H}, \mathrm{m}), 2.49-2.40(2 \mathrm{H}$, m), 2.32-2.20 (2H, m), $1.35(3 \mathrm{H}, \mathrm{t}, J=7.2 \mathrm{~Hz}) ;{ }^{13} \mathrm{C}$ NMR $\left(100.5 \mathrm{MHz}, \mathrm{CDCl}_{3}\right): \delta$ 166.8, 67.4, 66.7, 62.6, 58.6, 47.5, 34.1, 26.7, 26.6, 14.1. HRMS $\left(\mathrm{EI}^{+}\right): \mathrm{m} / \mathrm{z}$ calcd for $\mathrm{C}_{10} \mathrm{H}_{18} \mathrm{O}_{4} \mathrm{~S}_{2}: 266.0647$; found: 266.0646 . Chemical oxidation of $2(0.25 \mathrm{~g}, 1 \mathrm{mmol})$ according to the General Procedure D gave a mixture of stereoisomers 2a (95 mg, 63\%) which could be resolved on chiral HPLC.

Ethyl 2-(ethoxymethyl)[1,3]dithiane-2-carboxylate 1-oxide (3a). Ethyl 2-(ethoxymethyl)$[1,3]$ dithiane-2-carboxylate $(3,25 \mu \mathrm{L}, 0.11 \mathrm{mmol})$ was oxidized by yeast according to General Procedure $\mathrm{C}$ to give $3 \mathbf{a}(17 \mathrm{mg}, 64 \%)$ as a colorless oil. IR (neat): $\widetilde{v} 2978,2928,2871,1718$, 1225, 1116, $1056 \mathrm{~cm}^{-1}$; ${ }^{1} \mathrm{H}$ NMR (400 MHz, $\left.\mathrm{CDCl}_{3}\right): \delta 4.33(2 \mathrm{H}, \mathrm{m}) 4.30(2 \mathrm{H}, \mathrm{s}), 3.50(2 \mathrm{H}, \mathrm{m})$, $3.38(2 \mathrm{H}, \mathrm{m}), 3.13(1 \mathrm{H}, \mathrm{m}) 2.42(2 \mathrm{H}, \mathrm{m}), 2.30(1 \mathrm{H}, \mathrm{m}), 1.33(3 \mathrm{H}, \mathrm{t}, J=7.0 \mathrm{~Hz}), 1.20(3 \mathrm{H}, \mathrm{t}, J=$ $7.0 \mathrm{~Hz}) ;{ }^{13} \mathrm{C}$ NMR $\left(100.5 \mathrm{MHz}, \mathrm{CDCl}_{3}\right): \delta 166.0,69.8,67.8,63.8,62.7,47.7,27.8,26.5,14.8$, $14.2 \mathrm{ppm}$. HRMS $\left(\mathrm{EI}^{+}\right): \mathrm{m} / \mathrm{z}$ calcd for $\mathrm{C}_{10} \mathrm{H}_{18} \mathrm{O}_{4} \mathrm{~S}_{2}$ : 266.0647; found: 266.0646. Chemical oxidation of $3(0.25 \mathrm{~g}, 1 \mathrm{mmol})$ according to General Procedure E gave a mixture of stereoisomers 3a (168 mg, 64\%) which could be resolved on chiral HPLC.

2-Isobutyl[1,3]dithiolane-1-oxide (7a). 2-Isobutyl[1,3]dithiolane 7 (50 $\mu \mathrm{L} 0.55 \mathrm{mmol})$ was oxidized by yeast according to the General Procedure $\mathrm{C}$ in the presence of $\gamma$-cyclodextrin $(0.8 \mathrm{~g})$. The product was purified by chromatography using petroleum ether/ethyl acetate $(1: 1)$, followed by acetone as eluents to give $7 \mathrm{a}(56 \mathrm{mg}, 57 \%)$. E. coli-mediated oxidation of 7 (50 $\mu \mathrm{L}, 0.55 \mathrm{mmol})$ according to General Procedure D in the presence of $\gamma$-cyclodextrin $(0.5 \mathrm{~g})$ gave $7 \mathrm{a}(22.4 \mathrm{mg}$, 22\%). IR (neat): $\widetilde{v} 3466.9,2960,2927,2868,1472,1400,1058,939 \mathrm{~cm}^{-1} ;{ }^{1} \mathrm{H}$ NMR (400 MHz, $\left.\mathrm{CDCl}_{3}\right): \delta 4.16(1 \mathrm{H}, \mathrm{m}), 3.63(1 \mathrm{H}, \mathrm{m}), 3.39(2 \mathrm{H}, \mathrm{m}), 2.87(1 \mathrm{H}, \mathrm{m}), 1.79(2 \mathrm{H}, \mathrm{m}), 1.42(1 \mathrm{H}, \mathrm{m}), 0.983$ $(3 \mathrm{H}, \mathrm{d}, J=5.2 \mathrm{~Hz}), 0.935(3 \mathrm{H}, \mathrm{d}, J=3.2 \mathrm{~Hz}) ;{ }^{13} \mathrm{C} \mathrm{NMR}\left(100.5 \mathrm{MHz}, \mathrm{CDCl}_{3}\right): \delta 71.9,54.6,41.9$, 31.2, 27.2, 22.8, 21.6. Chemical oxidation of $7(0.5 \mathrm{~g}, 3.1 \mathrm{mmol})$ according to General Procedure $\mathrm{E}$ gave a mixture of stereoisomers $7 \mathbf{a}(443 \mathrm{mg}, 81 \%)$ which could be resolved on chiral HPLC.

2-Pentyl[1,3]dithiolane-1-oxide (8a). 2-Pentyl[1,3]dithiolane 8 (100 $\mu \mathrm{L}, 0.5 \mathrm{mmol})$ was oxidized by yeast according to General Procedure $\mathrm{C}$ in the presence of $\gamma$-cyclodextrin $(0.7 \mathrm{~g})$ gave 8a (95 mg, 96\%). IR (neat): $\widetilde{v} 2937,2853,1464,1047 \mathrm{~cm}^{-1} .{ }^{1} \mathrm{H}$ NMR (400 $\left.\mathrm{MHz}, \mathrm{CDCl}_{3}\right)$ : $\delta 4.13(1 \mathrm{H}, \mathrm{t}, J=3.2 \mathrm{~Hz}), 3.61(1 \mathrm{H}, \mathrm{m}), 3.31(2 \mathrm{H}, \mathrm{m}), 2.82(1 \mathrm{H}, \mathrm{m}), 1.95(1 \mathrm{H}, \mathrm{m}), 1.48(3 \mathrm{H}, \mathrm{m})$, $1.32(4 \mathrm{H}, \mathrm{m}), 0.91(3 \mathrm{H}, \mathrm{t}, J=3.5 \mathrm{~Hz}) .{ }^{13} \mathrm{C} \mathrm{NMR}\left(100.5 \mathrm{MHz}, \mathrm{CDCl}_{3}\right): \delta 73.6,54.5,32.9,31.2$, $31.3,27.7,22.2$, 13.8. E. coli mediated oxidation of $8(50 \mu \mathrm{L}, 0.25 \mathrm{mmol})$ according to General 
Procedure $\mathrm{D}$ in the presence of $\gamma$-cyclodextrin $(0.7 \mathrm{~g})$ gave a mixture of stereoisomers $8 \mathrm{a}(6 \mathrm{mg}$, $12 \%$ ) which could be resolved on chiral HPLC.

Ethyl 2-methyl[1,3]dithiolane-2-carboxylate 1-oxide (9a). Ethyl 2-methyl[1,3]dithiolane-2carboxylate $9(100 \mu \mathrm{L}, 0.5 \mathrm{mmol})$ was oxidized by yeast according to General Procedure $\mathrm{C}$ in the presence of $\gamma$-cyclodextrin $(0.7 \mathrm{~g})$ gave 9a $(56 \%, 0.25 \mathrm{~g})$. IR (neat): $\widetilde{v} 2980,2934,1731$, 1341, 1194, $1051 \mathrm{~cm}^{-1}$; ${ }^{1} \mathrm{H}$ NMR (400 MHz, $\left.\mathrm{CDCl}_{3}\right): \delta 4.15(2 \mathrm{H}, \mathrm{q}, J=3.6 \mathrm{~Hz}), 3.68(1 \mathrm{H}, \mathrm{m})$, $3.38(3 \mathrm{H}, \mathrm{m}), 2.99(2 \mathrm{H}, \mathrm{m}), 1.66(3 \mathrm{H}, \mathrm{s}), 1.25(3 \mathrm{H}, \mathrm{t}, J=3.6 \mathrm{~Hz}) ;{ }^{13} \mathrm{C} \mathrm{NMR}(100.5 \mathrm{MHz}$, $\left.\mathrm{CDCl}_{3}\right): \delta 168.8,72.8,61.2,55.2,44.2,31.4,20.7,14.1$. E. coli mediated oxidation of $9(50 \mu \mathrm{L}$, $0.25 \mathrm{mmol})$ according to General Procedure $\mathrm{C}$ in the presence of $\gamma$-cyclodextrin $(0.7 \mathrm{~g})$ gave 9a (25 mg, 50\%). Chemical oxidation of $9(0.416 \mathrm{~g}, 2 \mathrm{mmol})$ according to the General Grocedure D gave a mixture of stereoisomers 9a $(0.28 \mathrm{~g}, 64 \%)$. Only cis and trans diastereomers were resolved on chiral HPLC.

\section{Acknowledgments}

Support by the Natural Sciences and Engineering Research Council (NSERC) of Canada is gratefully acknowledged (M.M.K.). Some NMR spectra were recorded at the Atlantic Regional Magnetic Resonance Centre at Dalhousie University, Halifax, Canada.

\section{References}

1. Nakamura, S.; Watanabe, Y.; Toru, T. J. Org. Chem. 2000, 65, 1758.

2. Carreno, M. C. Chem. Rev. 1995, 95, 1717.

3. Kyung, K. H.; Han, D.C.; Fleming, H. P. J. Food Sci. 1997, 62, 406.

4. (a) Delatour, P.; Benoit, F.; Garnier, F.; Besse, S. J. Vet Pharmacol. Ther. 1990, 13, 361. (b) Kuzel, R. A.; Bhasin, S. K.; Oldham, H. C.; Damani, L. A.; Murphy, J.; Camilleri, P.; Hutt, A. J. Chirality 1994, 6, 607.

5. For a recent review see: Holland, H. L. Nat. Prod. Rep. 2001, 18, 171.

6. Ottolina, G.; Pasta, P.; Carrea, G.; Colonna, S.; Dallavale, S.; Holland, H. L. Tetrahedron: Asymmetry 1995, 6, 1375.

7. Colonna, S.; Gaggero, N.; Carrea, G.; Pasta, P. J. Chem. Soc., Chem. Commun. 1997, 439.

8. Ottolina, G.; Pasta, P.; Varley, D.; Holland, H. L. Tetrahedron: Asymmetry 1996, 7, 3427.

9. Colonna, S.; Gaggero, N.; Pasta, P.; Ottolina, G. J. Chem. Soc., Chem. Commun. 1996, 2303.

10. (a) Stewart, J. D.; Reed, K. W.; Kayser, M. M. J. Chem. Soc., Perkin Trans. I 1996, 755. (b) Kayser, M. M.; Chen, G.; Stewart, J. D. Synlett 1999, 153.

11. (a) Stewart, J. D.; Reed, K. W.; Martinez, C. A.; Zhu, J.; Chen, G.; Kayser, M. M. J. Am. Chem. Soc. 1998, 120, 3541. (b) Kayser, M. M.; Chen, G.; Stewart, J. D. J. Org. Chem. 
1998, 63, 7103.

12. Chen, G.; Kayser, M. M.; Mihovilovic, M. D.; Mrstic, M. E.; Martinez, C. A.; Stewart, J. D. New J. Chem. 1999, 827.

13. Light, D. R.; Waxman, D. J.; Walsh, C. Biochemistry 1982, 21, 2490.

14. Carrea, G.; Redigolo, B.; Riva, S.; Colonna, S.; Gaggero, N.; Battistel, E.; Bianchi, D. Tetrahedron: Asymmetry 1992, 3, 1063.

15. Secundo, F.; Carrea, G.; Dallavale, S.; Franzosi, G. Tetrahedron: Asymmetry 1993, 4, 1981.

16. Colonna, S.; Gaggero, N.; Bertinotti, A.; Carrea, G.; Pasta, P.; Bernardi, A. J. Chem. Soc., Chem. Commun. 1995, 1123.

17. Alphand, V.; Gaggero, N.; Colonna, S.; Furstoss, R. Tetrahedron Lett. 1996, 6117.

18. Colonna, S.; Gaggero, N.; Carrea, G.; Pasta, P. Tetrahedron: Asymmetry 1996, 7, 565.

19. Alphand, V.; Gaggero, N.; Colonna, S.; Pasta, P.; Furstoss, R. Tetrahedron 1997, 53, 9695.

20. (a) Auret, B. J.; Boyd, D. R.; Henbest, H. B. J. Chem. Soc. C 1968, 2371. (b) Holland, H. L.; Popperl, H.; Ninniss, R. W. Can. J. Chem. 1985, 63, 1118. (c) Ohta, H.; Okamoto, Y.; Tsuchihashi. G. Agric. Biol. Chem. 1985, 49, 671.

21. Beecher, J.; Richardson, P.; Roberts, S.; Willets, A. Biotech. Lett. 1995, 17, 1069.

22. Bulman Page P. C.; Allin, S. M.; Collington, E. W.; Carr, R. A. E. Tetrahedron Lett. 1994, 35, 2607.

23. Aggarwal, V. K.; Thomas, A.; Franklin, R. J. J. Chem. Soc., Chem. Commun. 1994, 1653.

24. Bulman Page P. C.; Wilkes, D. R.; Namwindwa, E. S.; Witty, M. J. Tetrahedron 1996, 52, 2125, and references cited therein.

25. Original reference: Chen, C.-S.; Fujimoto, Y.; Girdaukas, G.; Sih, C. J. J. Am. Chem. Soc. 1982, 104, 7294. The program for calculation is available at: $\underline{\text { http://www-org.tu-graz.ac.at }}$

26. Ottolina, G.; Carrea, G.; Colonna, S.; Rückemann, A. Tetrahedron: Asymmetry 1996, 7, 1123.

27. Jones, T. K.; Reamer, R. A.; Desmond, R.; Mills, S. G.; J. Am. Chem. Soc. 1990, 112, 2998.

28. Labiad, B.; Villenin, D. Synth. Commun. 1989, 19, 31.

29. Tavecchia, P.; Gentili, P.; Kurtz, M.; Sottani, C.; Bonfichi, R. Tetrahedron 1995, 51, 16.

30. Lissel, M. Synth. Commun. 1981, 11, 343.

31. Lee, J. G.; Hwang, J. Chem. Lett. 1995, 505.

32. Curini, M.; Epifano, F.; Marcotullio, M. C.; Rosati, O. Synlett 2001, 1182.

33. Muthusamy, S.; Babu, S.A.; Gunanathan, C. Tetrahedron Lett. 2001, 42, 359.

34. Kruse, C. G.; Wijsman, A.; van der Gen, A. J. Org. Chem. 1979, 44, 1847.

35. Seebach, D.; Corey, E. J. J. Org. Chem. 1975, 40, 231.

36. Carlson, R. M.; Helquist, P. M. J. Org. Chem. 1965, 33, 2596. 